\title{
Mateusz Jaworski
}

(Uniwersytet im. A. Mickiewicza w Poznaniu, Poznań - Polska)

\section{CZLOWIEK SPROWADZONY DO OBOZU. PRÓBA INTERPRETACJI TWÓRCZOŚCI WARŁAMA SZAŁAMOWA W KONTEKŚCIE FILOZOFII GIORGIO AGAMBENA}

Doświadczenie dwudziestowiecznych systemów totalitarnych, których przerażającym zwieńczeniem, a zarazem najstraszliwszym odkryciem były nazistowski obóz koncentracyjny, którego w niniejszej pracy będziemy metonimicznie nazywać Auschwitz, oraz sowiecki GUŁAG z wielką mocą wpłynęły na rozwój myśli humanistycznej, szczególnie w obszarach dyskursów filozoficznego i etycznego. Rzeczywistość Auschwitz i sowieckich łagrów, warunki w nich panujące oraz, last but not least, kondycja ludzi w nich więzionych wykazują niezwykłe podobieństwo. Oba systemy, pomimo usilnych starań zachowania pozorów przestrzegania prawa ze strony oprawców, stanowiły mechanizm, którego główną cechą była niespotykana dotychczas pogarda dla osoby ludzkiej. Zrozumienie istoty owej pogardy zdaniem włoskiego myśliciela Giorgio Agambena jest niemożliwe, jako że wykracza ona poza obszar wyrażalności. Aporia obozu polega bowiem na niemożliwości jego opisania wynikającej z jego wyjątkowej natury. Rzeczywistość obozu, twierdzi Agamben, z konieczności przerasta tworzące ją wydarzenia ${ }^{1}$. Pokazują one także, że „możliwa jest rozbieżność między faktami a prawdą, między możliwością ich stwierdzenia a możliwością ich zrozumienia"2.

Tak skomplikowane i ważne zjawisko nie mogło pozostać niezauważone przez sztukę, zwłaszcza przez literaturę. Ciągle wymykająca się odpowiedź na pytanie jak wyrazić realność obozu stymulowało rozwój szeroko rozumianej literatury obozowej, w odniesieniu do literatury rosyjskiej określanej jako łagrowa. Wśród pisarzy zajmujących się tą tematyką największą wiarygodność, a zatem i doniosłość, posiada działalność tych, którzy mieli bezpośredni kontakt z rzeczywistością obozu, tych, których moglibyśmy nazwać „świadkami“. W języku łacińskim, jak zauważa autor Homo Sacer, istniały dwa słowa określające świadka³. Pierwsze z nich - "testis", odnosi się wyłącznie do porządku prawnego,

\footnotetext{
${ }^{1}$ G. Agamben, Co zostaje z Auschwitz?, tłum. S. Królak, Warszawa 2008, s. 8.

2 Ibidem, s. 9.

${ }^{3}$ Ibidem, s. 15.
} 
oznaczając „kogoś, kto w postępowaniu sądowym bądź w sporze między dwiema stronami występuje w charakterze osoby trzeciej“4. Drugie z nich, "superstes", definiuje "tego, kto coś przeżył, przetrwał coś do samego końca, a zatem może dać temu świadectwo“5. Doskonałym przykładem świadka w znaczeniu „superstes”, tego który prze-trwał, który prze-żył, jest Warłam Szałamow. Rosyjski pisarz, autor słynnych Колымских рассказов, z całkowitą konsekwencją unikał wydawania ocen postępowania ludzi stanowiących część łagrowej codzienności. W opowiadaniu Заклинатель змей możemy odnaleźć dialog pomiędzy porte-parole autora - narratorem - i Płatonowem:

- Нет, - сказал я, - нет. Мне это казалось всегда последним унижением, концом. За суп я никогда не рассказывал романов. Но я знаю, что это такое. Я слышал "романистов".

- Это - осуждение? - сказал Платонов.

- Ничуть, - ответил я. - Голодному человеку можно простить многое, очень многое 6 .

Giorgio Agamben w pierwszym swoim dziele, w którym starał się wy-tłumaczyć fenomen Zagłady dokonanej na Żydach, Homo Sacer, będącym początkiem serii obozowych publikacji tego włoskiego filozofa ${ }^{7}$, szuka praprzyczyny rzeczywistości obozowej w zakłóceniu relacji pomiędzy życiem społecznym i naturalnym. Podział ten swoimi korzeniami sięga filozoficznej myśli Arystotelesa, który świadomie posługiwał się dwoma antagonistycznymi pojęciami „bios” i „zoẽ.. Pierwsze z nich oznacza życie, które zostało upolitycznione, drugie natomiast proste naturalne istnienie 8 . Podstawową różnicą występującą między nimi jest ich przynależność do dwóch, pozornie przeciwstawnych, sfer - "polis" i „oikos”, rozumianych odpowiednio jako społeczeństwo i dom. W tym świetle "zoẽ” jest tą częścią ludzkiej egzystencji, która teoretycznie wykluczona jest $\mathrm{z}$ wszelkich przejawów życia politycznego. Jednakże zarówno Giorgio Agamben, jak i Michel Foucault uważają, że dwudziestowieczna rzeczywistość $w$ pewien sposób usunęła wyraźną granicę pomiędzy „polis" i „oikos”, a więc także pomiędzy „bios” i „zoẽ":

Teza Foucault powinna więc zostać poprawiona, lub przynajmniej uzupełniona, w ten sposób, że tym, co najlepiej charakteryzuje współczesną politykę nie jest włączenie zoẽ do strefy polis - co było $\mathrm{w}$ pewnym sensie znane już w starożytności - ani nie jest

${ }^{4}$ Ibidem.

${ }^{5}$ Ibidem.

6 В. Шаламов, Заклинатель змей, [w:] В. Шаламов, Рассказы 30-х годов. Колымские рассказы, Москва 2004, s. 119.

${ }^{7}$ Do serii tej tradycyjnie zalicza się także jego: Stan wyjątkowy i Co zostaje z Auschwitz?

${ }^{8}$ G. Agamben, Homo Sacer. Sovereign Power and Bare Life, tłum. D. Heller-Roazen, Stanford 1998, s. 9 . 
tym fakt, że życie staję się głównym obiektem zainteresowania Państwa, rozumianego jako władza państwowa. Zamiast tego najbardziej trafnie charakteryzuje ją, wraz z procesem, w czasie którego wyjątek staje się regułą, sfera nagiego życia, to, że zoẽ, które zwykle usytuowane jest na marginesie strefy wpływów porządku politycznego, stopniowo zaczyna się z nim pokrywać; wyłączenie i włączenie, poza i wewnątrz, bios i zoe, prawo i fakt stają się niemożliwe do rozróżnienia9.

Miejscem, w którym „bios” i „zoẽ” stają się nierozerwalną całością jest Stan Wyjątkowy panujący w obozie ${ }^{10}$. Więźniowie pozbawieni są wszelkich praw politycznych, co oznacza redukcję ich egzystencji do „nagiego życia”. Ten pozorny akt depolityzacji został jednak zrealizowany w sposób na wskroś polityczny - Żydzi zostali zmuszeni do zrzeczenia się swojego obywatelstwa przed transportem do obozu, a ludzie zamykani w łagrach byli ofiarami pseudo-śledztw zwieńczonych pseudo-wyrokami opartymi na pięćdziesiątym ósmym artykule ${ }^{11}$. Najbardziej wyraźnym znakiem funkcjonowania "zoẽ w ramach "polis" jest żądza władzy nad każdą częścią życia więźniów, zwłaszcza zaś chęć zapanowania nad procesami fizjologicznymi ${ }^{12}$. Zredukowanie więźniów do „nagiego życia”, do „zoẽ”, pozwala oprawcom uzyskać nad nimi władzę nieskończoną - władzę, która decyduje które życie zasłużyło na dalsze istnienie, władzę nad życiem i śmiercią ${ }^{13}$. Dochodzimy w tym miejscu do sytuacji, w której ustalana jest granica, poza którą życie zostaje pozbawione jakiejkolwiek wartości w porządku prawnym. Życie takie może być zatem odebrane bez żadnej konsekwencji, jako "życie pozbawione wartości“, „życie niegodne dalszego istnienia”"14. Owe „życie pozbawione wartości" stanowi jedyną definicję agambenowskiego pojęcia „nagiego życia” doświadczanego przez „homo sacer” 15 .

${ }^{9}$ Ibidem, s. 12.

${ }^{10}$ Por.: G. Agamben, State of Exception, tłum. K. Attell, Chicago 2005.

11 Poza tym, wskazana przez Agambena podstawa prawna istnienia obozów koncentracyjnych, Schutzhaft, które pozwala na „zatrzymanie każdej osoby, bez względu jej działanie, jedynie $\mathrm{w}$ celu uchronienia bezpieczeństwa państwa przed niebezpieczeństwem grożącym z jej strony“, jest w praktyce bliźniacze z wyżej wymienionym artykułem. Por. G. Agamben, Homo Sacer..., op. cit., s. 95.

${ }^{12}$ Chęć ta widoczna jest także w maniakalnym wręcz ustalaniu porcji żywieniowych przydzielanych więźniom w łagrach. W opowiadaniu Szałamowa Сухим пайком z pełnym rozpaczy spokojem narrator komentuje normy żywieniowe zapisane w instrukcji obozowej: „Увы, даже полученные полностью нормы не могли питать, насыщать нас. Нам надо было втрое, вчетверо больше - организм каждого голодал давно". В. Шаламов, Сухим пайком, [w:] В. Шаламов, Рассказы..., ор. cit., s. 80.

${ }^{13}$ G. Agamben, Homo Sacer..., op. cit., s. 80.

${ }^{14}$ Ibidem, s. 81.

${ }^{15}$ Pojęcie „homo sacer” w myśli agambenowskiej używane jest w znaczeniu rzymskiego "przeklętego człowieka”, tj. „człowieka, który może być zabity, lecz nie poświęcony”. Ibidem, s. 12. 
Wielokrotnie pojawiający się w prozie Warłami Szałamowa podział na życie przed- i poobozowe ${ }^{16}$, rozumiany w kluczu agambenowskiej redukcji osoby ludzkiej do "nagiego życia” ogołoconego z wszelkiej godności, zdaje się znaczącą poszerzać obszar interpretacji twórczości autora По снегу. Fizjologiczna mania, znaczenie pokarmu w życiu zeków oraz cena, którą gotowi są za niego zapłacić w sposób okrutny, lecz zarazem wiarygodny, przedstawiają obraz więźnia jako człowieka przeklętego, "homo sacer", który, podobnie jak w opowiadaniu Ягоды, może zostać zabity bez żadnych konsekwencji ze strony oprawcy.

Krańcowym przypadkiem więźnia jest człowiek pozbawiony godności i głosu, pojawiający się w opowiadaniu Шерри-бренди ${ }^{17}$ pod postacią poety agambenowski "muzułman". "Muzułman" to "żywy trup", jak pisze Primo Levi, lub „ledwie trzymający się na nogach trup, kłębek fizycznych funkcji w ich ostatnich podrygach“, powtarzając za Johnem Amery ${ }^{18}$. Szałamow w przeciwieństwie do Agambena i wyżej wymienionych Leviego i Ameriego dociera do psychiki „muzułmana”, nie odbierając mu zdolności myślenia. Umierający poeta w Шерри-бренди ukazany jest zatem przede wszystkim w wymiarze duchowym. Pomimo tego, że dla otaczających go zeków jest leżącym godzinami bez ruchu ciałem, człowiekiem, który „умер раньше даты своей смерти“19, poeta przedstawiony jest jako podmiot poznający, który w ostatnich chwilach życia doświadcza epifanii ${ }^{20}$.

Filozoficzne rozmyślania Giorgio Agambena okazują się niezwykle pomocne przy pogłębionej analizie kondycji osoby ludzkiej funkcjonującej w ramach obozu w prozie Warłama Szałamowa. Zarówno pojęcia "nagiego życia" i "homo sacer", jak i rozumienie biopolitycznych zależności "zoẽ" od „bios” oraz głębokie pojmowanie znaczenia świadectwa przekazywanego przez "superstes", w dużym stopniu łączą działalność włoskiego filozofa i rosyjskiego pisarza. Idee Giorgio Agambena, który sam nazywa siebie jedynie komentatorem ${ }^{21}$, zdają się być obiecującym kontekstem interpretacyjnym $\mathrm{w}$ przyszłych badaniach twórczości autora Колымских рассказов.

16 Narrator w taki oto sposób opisuje Płatonowa w Заклинателе змей: „Андрей Федорович Платонов, киносценарист в своей первой жизни”. В. Шаламов, Заклинатель змей, [w:] В. Шаламов, Рассказы..., ор. cit., s. 118.

17 В. Шаламов, Шерри-бренди, [w:] В. Шаламов, Рассказы..., ор. cit., s. 101-105.

${ }^{18}$ G. Agamben, Co zostaje z Auschwitz?, op. cit., s. 41-42.

19 В. Шаламов, Шерри-бренди, [w:] В. Шаламов, Рассказы.., ор. сіt., s. 105.

${ }^{20}$ W Шерри-бренди czytamy: „Сейчас было так наглядно, так ощутимо ясно, что вдохновение и было жизнью; перед смертью ему дано было узнать, что жизнь была вдохновением, именно вдохновением". Ibidem, s. 103.

${ }^{21}$ G. Agamben, Co zostaje z Auschwitz?, op. cit., s. 9. 